Kul, Ü., Birişçi, S., \& Kutay, V. (2019). Use of Case Adaptation of Teachers' ICT Integration Proficiency Scale into Turkish. Bartın University Journal of Faculty of Education, 8(2), 437-456.

Bartın University Journal of Faculty of Education, 8(2), 437-456

Bartın Üniversitesi Eğitim Fakültesi Dergisi, 8(2), 437-456

buefad.bartin.edu.tr

\title{
Adaptation of Teachers' ICT Integration Proficiency Scale into Turkish
}

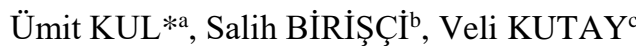

\begin{tabular}{l} 
Article Info \\
\hline DOI: $10.14686 /$ buefad.442836 \\
\hline Article History: \\
Received $\quad 11.07 .2018$ \\
Accepted $\quad 04.02 .2019$ \\
Published $\quad 30.06 .2019$ \\
\hline Keywords: \\
Teacher ICT Integration, \\
Proficiency, \\
Scale Adaptation, \\
Validity, \\
Reliability. \\
\hline Article Type: Research Article
\end{tabular}

\begin{abstract}
The aim of the present study is to explore validity and reliability of the Turkish adaptation of the "Teachers' ICT Integration Proficiency Scale" revised by Hsu (2017). After the translation stage, it was applied to a total of 362 teachers from different branches employed by different school types. The construct and concurrent validity were used to determine the validity of the scale. Confirmatory factor analysis completed for construct validity observed the Turkish form of the scale had 5 dimensions and that this model had good fit $(\chi 2=151.58, \mathrm{SD}=53, \mathrm{RMSEA}=0.08$, $\mathrm{GFI}=0.93, \mathrm{AGFI}=0.88, \mathrm{CFI}=0.95, \mathrm{NFI}=0.91, \mathrm{NNFI}=0.96$ ). For concurrent validity, there were significant correlations observed between "Teachers' Integration Proficiency Scale" and "Teachers' ICT Skills Scale". The Cronbach alpha coefficient and item-total correlations were examined to determine the reliability of the scale. The Cronbach alpha internal consistency reliability coefficients for the dimensions of the scale of preparation $(\alpha=.77)$, production $(\alpha=.83)$, instruction $(\alpha$ $=.90)$, development $(\alpha=.79)$ and issues $(\alpha=.79)$ were determined to have sufficient reliability. The correlation coefficients between the items and total of the Turkish form of the scale were found to vary from 0.37 to 0.69 . These results show that Turkish form of the scale is a valid and reliable scale.
\end{abstract}

\section{Öğretmenler için Bilgi ve İletişim Teknolojileri Entegrasyonu Yeterlikleri Ölçeğinin Türkçe'ye Uyarlanması}

\begin{tabular}{|c|c|}
\hline \multicolumn{2}{|c|}{ Makale Bilgisi } \\
\hline DOI: 1 & 686/buefad.442836 \\
\hline $\begin{array}{l}\text { Makale } \\
\text { Geliş } \\
\text { Kabul } \\
\text { Yayın }\end{array}$ & $\begin{array}{l}\text { mişi: } \\
11.07 .2018 \\
04.02 .2019 \\
30.06 .2019\end{array}$ \\
\hline $\begin{array}{l}\text { Anahta } \\
\text { Öğretm } \\
\text { Yeterli } \\
\text { Ölçek } \\
\text { Geçerl } \\
\text { Güven }\end{array}$ & $\begin{array}{l}\text { limeler: } \\
\text { İT entegrasyonu, } \\
\text { ama, }\end{array}$ \\
\hline $\begin{array}{l}\text { Makale } \\
\text { Makale }\end{array}$ & $\ddot{u}:$ Araştırma \\
\hline
\end{tabular}

$\ddot{O} z$

$\mathrm{Bu}$ araștırmanın amacı, Hsu (2017) tarafından yeniden gözden geçirilmiş olan öğretmenlerin bilgi ve iletişim teknolojileri entegrasyonu yeterliklerini ve zaman içindeki değişimlerini ölçmeyi amaçlayan ölçeğin Türkçe formunun geçerlik ve güvenirliğinin yapılarak sunulmasıdır. Türkçe form çeviri aşamalarından sonra farklı branşlarda ve okul kademelerinde görev yapmakta olan toplam 362 öğretmene uygulanmıştır. Ölçeğin geçerliğini belirleyebilmek için yapı ve uyum geçerliği kullanılmıştır. Yapı geçerliği için gerçekleştirilen doğrulayıcı faktör analizinde ölçeğin Türkçe formunun beş boyutlu olduğu ve bu modelin iyi uyum sağladığ1 görülmüştür $\left(\chi^{2}=151.58, \mathrm{SD}=53, \mathrm{RMSEA}=0.08, \mathrm{GFI}=0.93\right.$, AGFI=0.88, CFI=0.95, $\mathrm{NFI}=0.91$, NNFI=0.96). Uyum geçerliğinde "Öğretmenler için Bilgi ve İletişim Teknolojileri Entegrasyonu Yeterlikleri” ile "Öğretmenlerin Bilgi ve İletişim Teknolojileri Becerileri” ölçekler arasında anlamlı ilişkilere sahip olduğu görülmüştür. Ölçeğin güvenirliğini belirlemek için ise Cronbach alfa katsayısı ve madde-toplam korelasyonlarına bakılmıştır. Ölçeğin Cronbach alfa iç tutarlılık güvenirlik katsayılarının Hazırlık $(\alpha=.77)$, Üretim $(\alpha=.83)$, Öğretim $(\alpha=.90)$, Gelişim $(\alpha=.79)$ ve Konular/Sorunlar $(\alpha=.79)$ alt boyutlarında yeterli güvenilirlikte oldukları belirlenmiştir. Türkçe formda bulunan maddeler ile toplam arasındaki korelasyon katsayılarının 0.37 ile 0.69 arasında değiştiği bulunmuştur. Ulaşılan bu

\footnotetext{
*Corresponding Author: umitkul@artvin.edu.tr

a Asst. Prof. Dr., Coruh University, Artvin/Turkey, http://orcid.org/ 0000-0002-3651-4519

b Asst. Prof. Dr., Uludağ University, Bursa/Turkey, http://orcid.org/ 0000-0001-7131-5112

${ }^{c}$ Asst. Prof. Dr., Giresun University, Giresun/Turkey, http://orcid.org/ 0000-0002-8408-2183
} 
sonuçlar ölçeğin Türkçe formunun geçerli ve güvenilir bir ölçme aracı olduğunu göstermektedir. 


\section{Introduction}

Nowadays, the process of change in parallel with technological developments is visible in nearly all areas, including educational activities. Called the information age, in the 21st century developments in information and communication technologies (ICT) may affect the behaviour of individuals and communication forms within the educational process (Ertmer, 2005; MEB, 2017). When assessed from this aspect, within this timeframe, it is not wrong to say ICT should be dealt with as an important part of educational activities. This situation makes it necessary for individuals involved in educational activities to have a range of competencies to be able to include ICT as necessary. It is possible to define this structuring based on the necessity of including technology in educational environments as the integration process of technology into education (Çoklar \& Yurdakul, 2017; Haşlaman, Kuşkaya-Mumcu \& Usluel, 2007; Lawrence \& Tar, 2018; Mazman \& Usluel, 2011; Misırl1, 2016; Niederhauser \& Perkmen, 2008; So \& Kim, 2009; Tsai, 2015; Yalın, Karadeniz \& Şahin, 2007). There are a variety of definitions included in the relevant literature related to the technology integration process. Hew and Brush (2007) defined technology integration as teachers using all types of technology while completing teaching. However, Hsu (2010a) mentioned the need to consider having knowledge of the use of ICT alone as a form of technology integration and stated that this should be accepted as the only pre-condition for integration. Davies (2011) defined technology integration as the effective application of educational technologies to achieve the targeted learning outcomes. Based on reducing limitations of learning situations, Mumcu Haşlaman and Usluel (2008) explained technology integration as teacher's teaching strategies enriched with ICT and the efficacy of these on student learning. When definitions about the technology integration process are generally assessed, it is expected that by including current technologies in the teaching environment, teachers will benefit from these technologies as necessary.

Together with the technology integration process in education, there appear to be a variety of research related to increasing quality in education. This situation is reflected in the educational policies of many countries, and the interest in educational technologies appears to be increasing in both developed and developing countries (Tezci, 2011). When this situation is assessed in Turkey, initiatives began by the Ministry of National Education (MEB) have focused on the need to support developing the scope of technologies in teaching activities. The FATIH project, completed to disseminate technology integration with teaching and to ensure actively use by students and teachers, and the ICT applications included within the scope of this project is seen as one of the most current examples that can be shown as a source of development (MEB, 2011). With this project, work was performed to strengthen the technological infrastructure of educational organizations for technology integration with education, to create teaching materials and content and related to access. The target is to ensure an effective learning process together with technology integration with education. With the aim of supporting the use of these technologies within classrooms, standards of use for technology in education were determined. The International Society for Technology in Education (ISTE) was founded to provide teachers with the necessary proficiencies about technology such as being technologically literate, being able to use technology in lessons, being able to direct students' use of technology, being able to teach students the skills of accessing information and using information, organizing the learning environment so that they can use technology and being able to cooperate with colleagues via the internet (ISTE, 2014). In Turkey, these competencies are included in the Teaching Professional General Competencies document listing the proficiencies teachers must have to effective and productively perform in the teaching profession (MEB, 2017). This Ministry of National Education document includes many standards based on the point that teachers should effectively and productively benefit from computer and other technologies during activities in the education-teaching process along with competencies related to technology that teachers must have such as being technology literate. Whether on an international or national basis, when all proficiencies related to technology integration with education are generally assessed, the emphasis appears to be on markers at the point where individuals involved in educational work can effectively use technology within the framework of teaching and learning activities.

Teachers are seen as being one of the most effective factors in the race for educational innovation (Cenker \& Akgül, 2011). As a result, together with the transformation process occurring in learning environments, an important role falls to teachers at the point of effectively and productively including ICT resources in the learning and teaching processes as they are the people applying them (Ertmer, 2005; Kafyulilo, Fisser \& Voogt, 2016; Öçal \& Şimşek, 2017; Özerbaş, 2010). At this point it must be accepted that teachers need to have technology integration to transfer 21st century learning experiences to students (Jacobs, 2010). It is possible to find may studies in the relevant literature emphasizing the importance of teachers in the technology integration process (Çağlltay et al., 2001; Çırak \& Demir, 2014; Çoklar \& Yurdakul, 2017; Erişti, Kurt \& Dindar, 2012; Ertmer \& Ottenbreit, 2010; 
Hsu, 2010b; Ilgaz \& Usluel, 2011; Pittman \& Gaines, 2015; Yu-Liang, 2011). Lim (2007) mentioned the importance of teachers in their definition of technology integration, emphasizing the necessity of teachers' use of technology in completing teaching and learning activities effectively and productively. Similarly, Christensen (2002) mentioned the importance of teachers in the technology integration process stating that the teaching processes of teachers who integrate technology with the available syllabus differed compared to those who did not integrate it. When assessed from this aspect, the role of teachers in the integration of ICT with the learning-teaching process should not be ignored (Ilgaz \& Usluel, 2011). It is important to evaluate which ICT tools are included at which stages of teaching activities by teachers and the competency levels within this process. With this aim, many studies appear to be included in the relevant literature by researchers at both national and international levels. One of these types of studies involves the development of scales to identify the technology integration with education by teachers with the majority using situation identification studies. Niederhauser and Perkmen (2008) developed a scale with the aim of assessing internal, social and cognitive beliefs affecting teachers' tendency for technology integration, based on the lack of available scale tools. Additionally, a scale development study by Çakıroğlu, Gökoğlu and Çebi (2015) aimed to identify markers related to the integration process by teachers. Artun and Günüç (2016) approached assessing technology integration efficacy from a different angle. The researchers determined a scale to assess the technology integration sufficiency of teaching staff explaining lessons from a student perspective rather than having the individual responsible for explaining the lessons assess their own competency. However, Tezci (2016) developed a scale based on adopting different technology integration approaches to determine the proficiency of teachers at integrating ICT in the classroom. Together with the scale developed in this study, the desire was to attempt to reveal which approaches to technology were included in the learningteaching process.

It appears that scales used and developed in the relevant literature about teachers' technology integration proficiency focus on different dimensions. While assessing the technology literacy of teachers, it is recommended to include dimensions involving their pedagogical approaches, professional development and health, ethics and safety issues concerning technology usage (Howard \& Davies, 2009; Hsu, 2010b; Tondeur, van Braak \& Valcke, 2007). In Turkey there is no comprehensive scale investigating the above-mentioned dimensions of teacher's ICT integration proficiency. Also few studies have investigated changes in the level of teacher ICT integration proficiency over time. With the aim of determining the change over time of teachers' information and communication technology integration proficiencies, Hsu (2017) developed a scale. The translation of this scale to Turkish will both bring an important scale to Turkish literature and the data obtained when using the Turkish form of this scale can be compared to scientific data about ICT integration by teachers in other countries. This scale study with adaptation completed and analysis of teachers' levels of ICT use, experience and integration competency will produce scientific evidence for inquiries about the benefit of investments in technology and contribute to correct planning of support and training studies for teachers. As a result, this study is considered to contribute to a need, and aimed to determine the validity and reliability of this scale under Turkish culture.

\section{Method}

\section{Study Group}

The Turkish translation of the scale was applied to 362 primary school, middle school and high school teachers employed in five different provinces in Turkey. The provinces were selected according to the criteria of ease of access. Before this, the necessary permissions were obtained from the relevant provincial National Education Directorates. Later, the schools were selected according to criteria including the ease of access to the schools and research into the different school types. Later the schools were visited in person and after necessary information was given, teachers who volunteered were requested to complete the scale. 
Table 1. Demographic characteristics of participants

\begin{tabular}{lccc}
\hline \multirow{3}{*}{ Gender } & & $\mathbf{f}$ & $\boldsymbol{\%}$ \\
\cline { 2 - 4 } & Female & 212 & 58.6 \\
\cline { 2 - 4 } & Male & 150 & 41.4 \\
\cline { 2 - 4 } Years of Experience & $0-5$ & 118 & 32.6 \\
\cline { 2 - 4 } & $6-10$ & 94 & 26.0 \\
\cline { 2 - 4 } & $11-15$ & 59 & 16.3 \\
\cline { 2 - 4 } School Type & $16-20$ & 38 & 10.5 \\
\cline { 2 - 4 } & $20+$ & 53 & 14.6 \\
\cline { 2 - 4 } & Primary school & 108 & 29.8 \\
\cline { 2 - 4 } & Middle school & 193 & 53.3 \\
\hline
\end{tabular}

This application, with 212 female (58.6\%) and 150 (41.4\%) male teachers participating, asked teachers to first complete a personal information form, with the aim of identifying validity and reliability (see Table 1). Participants were from 38 different teaching fields, with the most common fields being primary classroom teachers at $14.9 \%$ (54 people), English teachers at $10.8 \%$ (39 people), primary school mathematics teachers at $8.8 \%$ (32 people), Turkish language and literature teachers at $7.7 \%$ (28 people) and Turkish teachers, and religious culture and moral values teaching at $5.8 \%$ each (21 people).

\section{Data Collection Tools}

In this study, the revised version of Teachers' Integration Proficiency Scale (TIPS) was used Hsu (2017). First developed by Dr. Hsu in 2010, the scale comprises 40 items grouped in a total of 6 subscales. This scale was applied to 3729 primary school (66\%) and middle school (34\%) teachers. In this study, the latest version of the scale translated to Turkish with validity and reliability measured was a continuation scale developed to be applied to the sample in the previous study. The scale used in this study comprises 6 sub-dimensions as in the previous study and contains 28 items. Twenty-three of these 28 items are common to the 40 -item scale. A study by Hsu (2017) aimed to measure the ICT integration proficiency of teachers employed at schools in Taiwan and to identify changes which occurred in ICT integration proficiency at the end of a 3-year duration. This scale is a 4-point Likert type scale (never, rarely, sometimes and often) comprising 28 items and 6 sub-dimensions.

Table 2. Six dimensions and item numbers for Hsu's (2017) TIPS scale

\begin{tabular}{l|c|c}
\hline Subscale & Item & Cronbach $\boldsymbol{\alpha}$ \\
\hline Preparation & 3 & 0.70 \\
\hline Production & 5 & 0.86 \\
\hline Communication & 2 & 0.68 \\
\hline Instruction & 10 & 0.94 \\
\hline Development & 3 & 0.75 \\
\hline Issues & 5 & 0.89 \\
\hline Total & 28 & 0.95 \\
\hline
\end{tabular}

The study also used the Teachers' ICT Skills Scale (TICTS) with the aim of measuring the concurrent validity of the scale. The TICTS scale was developed by Türel, Özdemir and Varol (2017) and comprises 16 items including statement about teachers' information and communication technology skills. This scale is a 5-point Likert type scale with responses of definitely disagree, disagree, partly agree, agree and definitely agree. The researchers gave the final form to the scale after three stages. The first stage created an 18-item, the second stage collected data from 304 teachers and the third stage used exploratory factor analysis with the aim of measuring the reliability and validity of the scale. At the end of the analysis, there were 3 dimensions with Cronbach alpha values of $.74, .85$ and .89 in a 16-item scale with validity and reliability proven. The 3 dimensions on the scale are 5-item 'Basic Hardware Operations', 5-item 'Personal ICT Usage' and 8-item 'Use of ICT for Teaching'.

\section{Translation Process}


Firstly, in order to perform the study, the creator of the scale, Hsu, working as professor at the Center for Teacher Education in National Taiwan University, was contacted and necessary permissions were obtained. The scale for reliability and validity analyses was first separately translated into Turkish by two researchers with doctoral education in UK and academic levels of both Turkish and English. All items on the scale were translated to Turkish taking great care not to disrupt the meaning of the item but adapted to Turkish speaking patterns. Then the separately completed translations were comparatively investigated, necessary changes and corrections were made and agreement was reached about the most accurate and most appropriate translation. In later stages, the Turkish translation of the scale was investigated by two experts with experience developing scales and each item was assessed both for sufficiency as a scale item and for accuracy and comprehension of the translation. As a result of feedback from the experts, scale items were revised again and necessary changes made. In the final stage, with consensus reached about the scale translation, it was translated to English by another English-language expert.

\section{Data Analysis}

In this study, reliability and validity analyses were completed on the translation for Turkish culture of the scale developed by Hsu (2017) to measure changes over time of teachers' ICT integration proficiency (TIPS) and the aim of dealing with psychometric features of the translated form. In this context, the Cronbach alpha reliability coefficient was calculated with the aim of determining the reliability. Additionally, item analysis with corrected item-total correlations were investigated. With the aim of determining the validity of TIPS, the construct and concurrent validity were dealt with. Confirmatory factor analysis was used for construct validity. Confirmatory factor analysis is a functional method used with the aim of determining the degree of consistency between factors forming linked to a present structure with real data (Kline, 2010; Tabachnick \& Fidell, 2007).

When interpreting the results of confirmatory factor analysis, different fit indices were considered. In this study, these included the chi-square goodness of fit degree of freedom ratio $\left(\chi^{2} / \mathrm{df}\right)$, Comparative Fit Index (CFI), Incremental Fit Index (IFI), Standardized Root Mean Square Residual (SRMR) and Root Mean Square Error of Approximation (RMSEA) values. As critical points for acceptability, $\chi^{2} / \mathrm{sd}=3$ (Briggs \& Cheek, 1986) is encountered, for CFI and IFI results above .90 are acceptable (Bentler, 1990; Brown, 2006; Hooper, Coughlan and Mullen, 2008). For SRMR and RMSEA, data smaller than .80 is stated to show good fit (Hu \& Bentler, 1999; Joreskog \& Sorbom, 1993; Schreiber et al., 2006). In addition to the goodness of fit indices in confirmatory factor analysis, it is expected the factor loadings for items comprising dimensions will be above .30 and significant.

For concurrent validity, the correlation coefficients for the TIPS and TICTS scales were investigated.

\section{Findings}

\section{Reliability}

The Cronback alpha coefficient was obtained for both subdimensions and the whole scale with the aim of identifying the reliability of TIPS. The results related to the Cronbach alpha reliability coefficient are given in Table 3.

Table 3. Reliability results of TIPS

\begin{tabular}{lcc}
\hline Subscale & Item & Cronbach $\boldsymbol{\alpha}$ \\
\hline Preparation & 3 & .77 \\
Production & 5 & .83 \\
Communication & 2 & .48 \\
Instruction & 10 & .90 \\
Development & 3 & .79 \\
Issues & 5 & .79 \\
\hline
\end{tabular}

As seen on Table 3, when investigated in terms of Cronbach alpha coefficient, the alpha value of the communication dimension is .48 and as a result, was identified not to be reliable as this value is lower than .70 . The other dimensions of preparation $(\alpha=.77)$, production $(\alpha=.83)$, instruction $(\alpha=.90)$, development $(\alpha=.79)$ and issues $(\alpha=.79)$ were determined to have sufficient reliability. 
After the Cronbach alpha reliability coefficient was calculated, the corrected item-total correlations for TIPS items were investigated and are presented in Table 4.

Table 4. Corrected item total correlations for TIPS

\begin{tabular}{|c|c|c|c|c|}
\hline Subscale & Item & $r_{j x}$ & $\mathbf{M}$ & SD \\
\hline \multirow{3}{*}{ Preparation } & 1 & .616 & 3.64 & .65 \\
\hline & 2 & .653 & 3.57 & .62 \\
\hline & 3 & .568 & 3.19 & .74 \\
\hline \multirow{5}{*}{ Production } & 4 & .605 & 3.11 & .84 \\
\hline & 5 & .617 & 2.51 & .93 \\
\hline & 6 & .628 & 2.65 & .88 \\
\hline & 7 & .668 & 2.93 & .94 \\
\hline & 8 & .619 & 3.03 & .79 \\
\hline \multirow{2}{*}{ Communication } & 9 & .319 & 2.73 & .95 \\
\hline & 10 & .319 & 1.79 & .94 \\
\hline \multirow{10}{*}{ Instruction } & 11 & .513 & 2.93 & .84 \\
\hline & 12 & .654 & 2.28 & .96 \\
\hline & 13 & .664 & 2.44 & .90 \\
\hline & 14 & .660 & 2.35 & .97 \\
\hline & 15 & .685 & 2.72 & .88 \\
\hline & 16 & .670 & 2.29 & 1.01 \\
\hline & 17 & .717 & 2.24 & .95 \\
\hline & 18 & .679 & 2.46 & .92 \\
\hline & 19 & .621 & 2.11 & 1.00 \\
\hline & 20 & .734 & 2.11 & .99 \\
\hline \multirow{3}{*}{ Development } & 21 & .560 & 2.65 & .92 \\
\hline & 22 & .685 & 2.35 & .98 \\
\hline & 23 & .650 & 2.01 & .90 \\
\hline \multirow{5}{*}{ Issues } & 24 & .613 & 3.90 & .95 \\
\hline & 25 & .643 & 3.84 & .96 \\
\hline & 26 & .678 & 4.12 & .89 \\
\hline & 27 & .616 & 4.07 & .79 \\
\hline & 28 & .365 & 3.18 & 1.11 \\
\hline
\end{tabular}

Table 4 shows the corrected item-test correlation for the scale as a result of item analysis completed with the aim of determining the predictive and differentiating power for total points of TIPS items. When Table 4 is investigated, it appears the items can be listed as follows; preparation (.568 to .653), production (.605 to .668), communication (.319), Instruction (.513 to .734), development (.560 to .685) and issues (.365 to .678), Investigation of item total correlations considering that items with 0.30 or higher distinguish the required dimensions well (Büyüköztürk, 2007) and that the Cronbach alpha reliability coefficient should be above .70 (Nunnaly, 1978) indicated that the communication dimension should be removed from the scale tool. Construct validity was completed on the scale with 5 dimensions and 26 items.

\section{Construct Validity}

For construct validity of TIPS, with the aim of testing whether the construct of the original form was confirmed by teachers with the Turkish form, standardized factor loads and explained variance for items related to confirmatory factor analysis are included in Table 5. 
Table 5. CFA results for TIPS

\begin{tabular}{|c|c|c|c|}
\hline Item & $\lambda$ & $\boldsymbol{\theta}$ & $\boldsymbol{R}^{2}$ \\
\hline 1. Used a computer to create lecture notes, class material and exam questions & 67 & .24 & .45 \\
\hline $\begin{array}{l}\text { 2.Used the Internet or other information technology to search for information to provide } \\
\text { supplementary course material for students }\end{array}$ & .76 & .17 & .57 \\
\hline 3. Spent time to select media or ICT material that fit the curricula and lesson goals & .76 & .23 & .58 \\
\hline 4. Used presentation software to present course material in class & .71 & .35 & .50 \\
\hline $\begin{array}{l}\text { 5. Solved hardware problems during class (e.g. no signal on the projector or the computer } \\
\text { is down) }\end{array}$ & 69 & .45 & .48 \\
\hline $\begin{array}{l}\text { 6. Followed the Competence Indicators of Grades 1-9 curricula to design the course which } \\
\text { involved media }\end{array}$ & .70 & .40 & .49 \\
\hline 7. Used the computer to record, edit sound or music in my course material & .71 & .44 & .50 \\
\hline 8. Used technology to try new ways of teaching & .71 & .30 & .51 \\
\hline $\begin{array}{l}\text { 11. Instructed students on how to search for useful resources from the web for academic } \\
\text { learning }\end{array}$ & .58 & .47 & .34 \\
\hline 12. Divided students into groups while teaching ICT integrated lessons & .70 & .46 & .50 \\
\hline $\begin{array}{l}\text { 13. Ensure beforehand all the students have sufficient ICT resources and skills to complete } \\
\text { the homework }\end{array}$ & .71 & .40 & .51 \\
\hline $\begin{array}{l}\text { 14. Provided worksheets for students when requiring the use of web information to } \\
\text { complete the homework }\end{array}$ & .70 & .48 & .49 \\
\hline $\begin{array}{l}\text { 15. Used ICT to facilitate students' high level thinking ability such as creativity, analysis, } \\
\text { and judgement }\end{array}$ & .75 & .34 & .56 \\
\hline $\begin{array}{l}\text { 16. Assigned students' grade by including student's IT performance to provide alternative } \\
\text { grades to paper-and-pencil exam }\end{array}$ & .66 & .58 & .43 \\
\hline $\begin{array}{l}\text { 17. Analysed students' learning progress in group activities in ICT integrated lessons and } \\
\text { included them in evaluation }\end{array}$ & .70 & .45 & .49 \\
\hline $\begin{array}{l}\text { 18. Reviewed my own ICT Integrated units and strategies to find ways to improve the } \\
\text { lesson }\end{array}$ & .73 & .40 & .53 \\
\hline $\begin{array}{l}\text { 19. Designed ICT integrated homework so students without home computers can also } \\
\text { participate }\end{array}$ & .61 & .62 & .37 \\
\hline 20. Designed different ICT learning activities for students with different achievement level & .75 & .43 & .56 \\
\hline 21. Spent time to learn and practice ICT skills & .73 & .39 & .54 \\
\hline 22. Used online data base or online courses for professional development & .74 & .43 & .55 \\
\hline 23. Attended conferences or read journals to learn about ICT integration methods & .76 & .34 & .58 \\
\hline 24. Taught students the issues of internet ethics and rules before they used the Internet & .68 & .48 & .46 \\
\hline 25. Asked student to obey the intellectual property rights & .80 & .33 & .64 \\
\hline 26. Be aware of the problems of teenager addiction to the internet and the adult website & .80 & .28 & .64 \\
\hline $\begin{array}{l}\text { 27. Let students know how the possibility of using massive IT tools affect health, such as } \\
\text { disrupted schedule and bad eye sight }\end{array}$ & .68 & .33 & .47 \\
\hline $\begin{array}{l}\text { 28. Followed up and checked students who are having low spirit and sliding grade for } \\
\text { Internet addiction }\end{array}$ & .42 & .78 & .18 \\
\hline
\end{tabular}

Note. $\lambda=$ standardized factor loadings; $\theta=$ error variance

The factor loads for TIPS items vary from .42 to .80 with factor loads above .30 and accepted as significant. The fit indices for the scale appear to be as follows; $\chi^{2}(287, \mathrm{~N}=362)=749.07, \chi^{2} / \mathrm{sd}=2.61 ; \mathrm{CFI}=.90 ; \mathrm{IFI}=.90$; $\mathrm{SRMR}=.077$; RMSEA $=.067 \% 90 \mathrm{G} . \mathrm{A} .(.061-.073)$. As a result, the TIPS can be said to ensure construct validity. The findings related to criteria abiding situations in confirmatory factor analysis results are presented in Table 6 . 
Table 6. Confirmatory Factor Analysis Results for TIPS

\begin{tabular}{lccc}
\hline \multicolumn{1}{c}{ Fit index } & Calculated value & Acceptable value & Result \\
\hline$\chi^{2} / \mathrm{sd}$ & 2.61 & $\chi^{2} / \mathrm{sd} \leq 5.00$ & Accepted \\
CFI & .90 & $\mathrm{CFI} \geq .90$ & Accepted \\
IFI & .90 & $\mathrm{TLI} \geq .90$ & Accepted \\
SRMR & .077 & SRMR $\leq .08$ & Accepted \\
RMSEA & .067 & RMSEA $\leq .08$ & Accepted \\
\hline
\end{tabular}

Note. Acceptable values were noted from recommendations in Bollen, 1990, Hooper, Coughlan and Mullen, 2008, Hu and Bentler, 1999 and Joreskog and Sorbom 1993.

\section{Concurrent Validity}

Within the scope of concurrent validity of TIPS, the correlation with the TICTS scale adapted to Turkish by Türel, Özdemir and Varol (2017) was investigated. The findings related to the correlation between TIPS and TICTS are included in Table 7.

Table 7. Results of concurrent validity for TIPS

\begin{tabular}{lccc}
\hline Dimension & $\begin{array}{c}\text { Basic Hardware } \\
\text { Operations }\end{array}$ & Personal ICT Usage & Use of ICT for Teaching \\
\hline Preparation & $.31^{* *}$ & $.43^{* *}$ & $.58^{* *}$ \\
Production & $.50^{* *}$ & $.61^{* *}$ & $.63^{* *}$ \\
Instruction & $.37^{* *}$ & $.55^{* *}$ & $.48^{* *}$ \\
Development & $.43^{* *}$ & $.59^{* *}$ & $.50^{* *}$ \\
Issues & $.47^{* *}$ & $.63^{* *}$ & $.62^{* *}$ \\
\hline
\end{tabular}

Note. ${ }^{* *} p<.001$

The correlation between the TIPS and TICTS dealt with in the scope of concurrent validity is a positive and significant relationship. When the dimensions are investigated singly, preparation had correlations with basic hardware operations $(r=.31, p<.01)$, personal ICT usage $(r=.43, p<.01)$ and use of ICT for teaching $(r=.58$, $p<.01)$. The production dimension had correlations with basic hardware operations $(r=.50, p<.01)$, personal ICT usage $(r=.61, p<.01)$ and use of ICT for teaching $(r=.63, p<.01)$. Additionally, there were correlations between instruction with basic hardware operations $(r=.37, p<.01)$, personal ICT usage $(r=.55, p<.01)$ and use of ICT for teaching $(r=.48, p<.01)$. Similarly, development had a positive significant correlation with basic hardware operations $(r=.43, p<.01)$, personal ICT usage $(r=.59, p<.01)$ and use of ICT for teaching $(r=.50$, $p<.01)$. Finally, issues had positive significant correlations with basic hardware operations $(r=.47, p<.01)$, personal ICT usage $(r=.63, p<.01)$ and use of ICT for teaching $(r=.62, p<.01)$. In light of all these results, it can be said TIPS has concurrent validity.

\section{Conclusion and Recommendation}

The aim of this research was to translate the teachers' information and communication technology integration proficiency (TIPS) scale to Turkish and perform validity and reliability analyses on the scale. Construct and concurrent validity were used to determine the validity of the scale. Confirmatory factor analysis completed for construct validity observed the Turkish form of the scale had 5 dimensions and that this model had good fit $\left(\chi^{2}=151.58, \mathrm{SD}=53, \mathrm{RMSEA}=0.08, \mathrm{GFI}=0.93\right.$, AGFI=0.88, CFI=0.95, NFI=0.91, NNFI=0.96). For concurrent validity, a significant correlation was observed between TIPS and TICTS. The Cronbach alpha coefficient and item-total correlations were examined to determine the reliability of the scale. The Cronbach alpha internal consistency alpha coefficients for the scale were preparation $(\alpha=.77)$, production $(\alpha=.83)$, instruction $(\alpha=.90)$, development $(\alpha=.79)$ and issues $(\alpha=.79)$ which were determined to be sufficiently reliable. The correlation coefficients between the items found on the Turkish form and the totals varied from 0.37 to 0.69 . These results show that the Turkish form of the scale is a valid and reliable scale. 
In conclusion, the Turkish adaptation of the teachers' ICT integration proficiency scale comprises five dimensions, with this model providing good fit to data obtained from teachers participating in the research, with the internal consistency coefficients of the scale's dimensions at sufficient levels; thus, the scale serves its purpose. Considering these results, the Turkish adaptation of TIPS may be used to measure the changes over time of teachers' information and communication technology integration proficiency for all teachers employed in different branches and different school types (primary school, middle school and high school). Results obtained from research using the adapted scale will contribute to supporting the validity and reliability. The data obtained using the Turkish form of this scale will make it possible to compare scientific data related to ICT integration proficiencies with teachers in other countries. Additionally, validity and reliability studies for TIPS can be performed again with different samples. 


\title{
Öğretmenler İçin Bilgi ve İletişim Teknolojileri Entegrasyonu Yeterlikleri Ölçeğinin Türkçe'ye Uyarlanması
}

\author{
Giriş
}

Günümüzde yaşanan teknolojik gelişmeler paralelindeki değişim sürecini hemen hemen her alanda olduğu gibi eğitim faaliyetleri alanında da görmek mümkündür. Bilgi çağı olarak adlandırılan 21. yüzyılda, bilgi ve iletişim teknolojilerinde (BİT) yaşanan gelişmeler, eğitim sürecinde yer alan bireylerin davranışları ve iletişim biçimleri üzerinde etkili olabilmektedir (Ertmer, 2005; MEB, 2017). Bu açıdan değerlendirildiğinde, içinde bulunulan zaman diliminde BİT kavramının eğitim faaliyetlerinin önemli bir parçası olarak ele alınması gerektiğini söylemek yanlış olmayacaktır. Bu durum, eğitim faaliyetlerinde yer alan bireylerin BİT’lere gerektiği şekilde yer verebilmeleri için bir takım yeterliklere sahip olabilmelerini gerekli kılmaktadır. Teknolojiye eğitim ortamlarında yer verilmesi gerekliliğinden hareketle oluşan bu yapılanmayı, eğitimde teknoloji entegrasyon süreci şeklinde tanımlamak mümkündür (Çoklar ve Yurdakul, 2017; Haşlaman, Kuşkaya-Mumcu \& Usluel2007; Lawrence ve Tar, 2018; Mazman ve Usluel, 2011; Misırl1, 2016; Niederhauser ve Perkmen, 2008; So ve Kim, 2009; Tsai, 2015; Yalın, Karadeniz ve Şahin, 2007).

İlgili alanyazında teknoloji entegrasyon süreciyle ilgili çeşitli tanımlara yer verildiği görülmektedir. Hew ve Brush (2007) teknoloji entegrasyonunu öğretmenlerin öğrenmelerin gerçekleştirilmesi esnasında kullandıkları her tür teknoloji olarak tanımlamaktadır. Öte yandan sahip olunan BíT kullanımı bilgisinin başlı başına teknoloji entegrasyonu olarak düşünülmemesi gerektiğine değinen Hsu (2010a), bunun sadece entegrasyon için ön şart olarak kabul edilmesi gerektiğini belirtmektedir. Davies (2011) teknoloji entegrasyonunu, amaçlanan öğrenme çıktılarının gerçekleştirilmesi için eğitim teknolojilerinin etkili bir şekilde uygulanması olarak tanımlamaktadır. Öğrenme durumlarının sınırlılıklarını azaltmasından hareketle Mumcu, Haşlaman ve Usluel (2008) teknoloji entegrasyonunu, öğretmenlerin BİT ile zenginleştirilmiş öğretim stratejilerini uygulaması ve bunun öğrencilerin öğrenmeleri üzerindeki etkililiği olarak açıklamaktadır. Teknoloji entegrasyon sürecine yönelik yapılan tanımlar genel olarak değerlendirildiğinde, güncel teknolojilere öğretim ortamlarında yer verilmesiyle öğretmenlerin bu teknolojilerden gerektiği șekilde faydalanmaları beklenmektedir. Eğitimde teknoloji entegrasyon süreciyle birlikte eğitimde kalitenin arttırılmasına ilişkin çeşitli çalışmaların yapıldığı görülmektedir. Bu durum, birçok ülkenin eğitim politikalarına yansımış olmakla birlikte özellikle gelişmiş ve gelişmekte olan ülkelerde eğitim teknolojilerine olan ilginin giderek arttı̆̆ görülmektedir (Tezci, 2011). Ülkemiz açısından bu durum değerlendirildiğinde, Milli Eğitim Bakanlığı'nca (MEB) gerçekleştirilen atılımlarda, eğitim-öğretim faaliyetlerinin gelişen teknolojiler kapsamında desteklenmesi gerektiği üzerinde durulmaktadır. Eğitimde teknoloji entegrasyonunun yaygınlaştırılması ve öğrenci ile öğretmenlerce aktif kullanımının sağlanması noktasında gerçekleştirilen FATİH projesi ve bu kapsamda yer verilen BİT uygulamaları, yaşanan gelişmelere kaynak olarak gösterilebilecek en güncel örnekler olarak karşımıza çıkmaktadır (MEB, 2011). Bu proje ile eğitimde teknoloji entegrasyonuna yönelik eğitim kurumlarının teknolojik alt yapılarının güçlendirilmesi ve eğitsel ders materyalleri ve içeriklerinin oluşturulması ve erişime sunulmasına ilişkin çalışmalar yapılmaktadır.

Eğitimde teknoloji entegrasyonuyla birlikte etkin bir öğrenme sürecinin gerçekleşmesi hedeflenmektedir. Bu süreçte yer verilen teknolojilerin sınıf içinde kullanımını desteklemek amacıyla eğitimde teknoloji kullanımı standartlarının ortaya konulduğu belirlenmiştir. Uluslararası Eğitimde Teknoloji Derneği (ISTE), öğretmenlerin teknoloji konusunda sahip olması gereken yeterlikleri; teknoloji okuryazarı olma, derslerinde teknolojiyi kullanabilme, öğrencilerini teknoloji kullanmaya yöneltebilme, öğrencilerine bilgiye ulaşma ve bilgiyi kullanma becerilerini kazandırabilme, öğrenme çevresini teknoloji kullanabilecekleri şekilde düzenleyebilme ve meslektaşları ile İnternet üzerinden iş birliği yapabilme olarak belirlemiştir (ISTE, 2014). Türkiye'de ise bu yeterlikler, MEB tarafından öğretmenlik mesleğinin etkili ve verimli olarak yerine getirilmesinde öğretmenlerin sahip olması gereken yeterliklerin sıralandığı Öğretmenlik Mesleği Genel Yeterlikleri dokümanında yer almaktadır (MEB, 2017). İlgili dokümanda, teknoloji ile ilgili öğretmenlerin sahip olması gereken yeterliklerde, teknoloji okuryazarı olunmasıyla beraber bilgisayar ve diğer teknolojilerden eğitim ve öğretim sürecindeki faaliyetlerinde etkin ve verimli bir şekilde yararlanılması noktasında pek çok standardın yer aldığı görülmektedir. Gerek uluslararası gerekse ulusal bazda eğitimde teknoloji entegrasyonuna ilişkin ortaya konan tüm bu yeterlikler genel olarak değerlendirildiğinde, eğitim kademesinde yer alan bireylerin öğretme ve öğrenme faaliyetleri çerçevesinde teknolojinin etkin kullanabilmesi noktasındaki göstergelerin vurgulandığı görülmektedir. 
Öğretmenler, meydana gelen eğitimsel yeniliklerin işe koşulmasında en etken faktörlerden biri olarak kabul edilmektedir (Cenker ve Akgül, 2011). Bu sebeple, öğrenme ortamlarında meydana gelen dönüşüm süreciyle birlikte BITT kaynaklarını öğrenme ve öğretme süreçlerinde etkili ve verimli şekilde yer verilmesi noktasında, uygulayıcı konumunda olan öğretmenlere önemli roller düşmektedir (Ertmer, 2005; Kafyulilo, Fisser ve Voogt, 2016; Öçal ve Şimşek, 2017; Özerbaş, 2010;). Öğretmenlerin öğrencilerine, 21. yüzyıl öğrenme deneyimlerini aktarma noktasında teknoloji entegrasyonuna sahip olmaları gerektiği kabul edilmelidir (Jacobs, 2010). Alanyazında teknoloji entegrasyonu sürecinde öğretmenin önemini vurgulayan pek çok çalışmayla karşılaşmak mümkündür (Çağıltay, Çakıroğlu, Çağıltay \& Çakıroğlu, 2001; Çırak ve Demir, 2014; Çoklar ve Yurdakul, 2017; Erişti, Kurt \& Dindar, 2012; Ertmer ve Ottenbreit, 2010; Hsu, 2010b; Ilgaz ve Usluel, 2011; Pittman ve Gaines, 2015; Yu-Liang, 2011). Lim (2007) teknoloji entegrasyonuyla ilgili tanımında öğretmenin önemine değinirken, öğretme ve öğrenme etkinliklerinin etkili ve verimli olarak gerçekleştirilmesinde öğretmenin teknolojiden faydalanması gerektiğini vurgulamaktadır. Benzer şekilde teknoloji entegrasyon sürecinde öğretmenin önemine değinen Christensen (2002), teknolojiyi mevcut müfredata entegre eden öğretmenlerin öğretim süreçlerinin, etmeyenlere kıyasla farklılaştı̆ıını belirtmektedir. Bu açıdan değerlendirildiğinde, BİT'in öğrenme-öğretme sürecindeki entegrasyonunda öğretmenin rolü göz ardı edilmemesi gereken bir durumdur (Ilgaz ve Usluel, 2011).

Öğretmenlerin öğretim faaliyetleri kapsamında BİT araçlarına hangi aşamalarda yer verdikleri ve bu süreçteki yeterlik düzeylerinin değerlendirmesi önemlidir. $\mathrm{Bu}$ amaçla, araştırmacılarca gerek ulusal gerekse uluslararası düzeyde birçok çalışmanın alanyazına kazandırıldığı görülmektedir. $\mathrm{Bu}$ çalışma türlerinden biri olarak öğretmenlerin eğitimde teknoloji entegrasyonu durumlarının tespitine yönelik ölçekler geliştirilmiş olup bunların büyük kısmından durum tespiti amaçlı faydalanıldığı belirlenmiştir. Niederhauser ve Perkmen (2008), mevcut ölçme araçlarının eksikliğinden hareketle, öğretmenlerin teknoloji entegrasyonuna eğilimlerini etkileyen iç, sosyal, bilişsel inançlarının değerlendirilmesi amaçlı ölçek geliştirmişlerdir. Bunların yanı sıra, Çakıroğlu, Gökoğlu \& Çebi(2015)'nin yapmış olduğu ölçek geliştirme çalı̧̧masında öğretmenlerin entegrasyon sürecine ilişkin göstergelerinin tespit edilmesi amaçlanmıştır. Artun ve Günüç (2016) teknoloji entegrasyonu yeterliğinin değerlendirmesine farklı bir açıdan yaklaşmışlardır. Araştırmacılar çalışmalarında, ders anlatımında sorumlu bireyin kendi yeterliğinin değerlendirilmesinden ziyade, ders anlatımını gerçekleştiren öğretim elemanının teknoloji entegrasyonu yeterliğinin öğrenci algısı üzerinden değerlendirilmesine yönelik bir ölçek ortaya koymuşlardır. Öte yandan Tezci (2016)'nin geliştirmiş olduğu ölçek, farklı teknoloji entegrasyon yaklaşımlarının benimsenmesinden hareketle öğretmenlerin BİT'i sınıflarında entegre etmelerindeki yeterliklerinin belirlenmesine yönelik hazırlanmıştır. Bu çalışmada geliştirilen ölçekle birlikte, eğitim ve öğretim süreçlerinde teknolojiye hangi yaklaşım dahilinde yer verilmeye çalışıldığı ortaya çıkarılmak istenmiştir.

Alanyazın çalışmalarında, teknoloji entegrasyonu amaçlı öğretmenlere yönelik geliştirilen ölçme araçlarının farklı boyutlara odaklandıkları görülmektedir. Öğretmenlerin teknoloji okuryazarlığı değerlendirilirken onların pedagojik yaklaşımları, mesleki gelişimleri ve ortaya çıkan etik ve güvenlik konularını/sorunlarını içeren boyutların yer alması önerilmektedir (Howard ve Davies, 2009; Hsu, 2010b; Tondeur, van Braak ve Valcke, 2007). Türkiye'de öğretmenlerin BİT entegrasyon yeterliklerini yukarıda bahsedilen boyutlarıyla inceleyen kapsamlı bir ölçeğe rastlanılmamıştır. Öğretmenlerin bilgi ve iletişim teknolojileri entegrasyonu yeterliklerinin zaman içindeki değişimlerini belirlemek amacıyla Hsu (2017) tarafından geliştirilen ölçek, Türkçeye tercüme edilerek kullanıldığg takdirde hem bu önemli ölçek Türkçeye kazandırılmış olacak hem de bu ölçeğin Türkçe formunu kullanarak elde edilen verileri diğer ülkelerdeki öğretmenlerin BİT entegrasyonu yeterlikleriyle ilgili bilimsel verilerle karşılaştırmak mümkün olacaktır. Uyarlaması gerçekleştirilecek olan ölçek çalışması ile birlikte öğretmenlerin, BíT'i kullanmaya ilişkin düzeyleri, kullanım deneyimleri ve entegrasyon yeterliklerinin analiz edilmesi hem teknolojiye yapılan yatırımların işe yararlığını sorgulamada bilimsel kanıt üretecek hem de öğretmenlere verilmesi gereken destek ve eğitim çalışmalarının doğru planlanmasına katkı sağlayacaktır. Bundan dolayı, bu çalışmada, ihtiyaç duyulan gereksinimi karşılayabileceği düşünülerek, bahsi geçen ölçeğin Türkiye koşullarında geçerliğinin ve güvenilirliğinin belirlenmesi amaçlanmıştır.

\section{Yöntem}

\section{Çalıșma Grubu}

Bu çalışmada, Türkçeye çevirisi yapılan ölçek Artvin, Bursa, Erzincan, Giresun ve Mersin illerinde görev yapan 362 ilkokul, ortaokul ve lise öğretmenine uygulandı. Çalışmanın yapılacağı iller, erişim kolaylı̆̆ı ölçütüne göre seçildi. Bu uygulamanın yapılması öncesinde bahsi geçen illerin Milli Eğitim Müdürlüklerinden gerekli 
izinler alındı. Sonra uygulamanın yapılacağı okullar erişim kolaylığı ve farklı okul türlerinin araştırmaya dahil olması ölçütlerine göre belirlendi. Belirlenen okullara bizzat gidilerek öğretmenlere gerekli bilgilendirme yapıldıktan sonra gönüllü olan öğretmenlerden ölçeği doldurmaları istendi. Ölçeğin doldurulması öncesinde katılımcıların kişisel bilgileri hazırlanan bir form aracılığıyla alındı (Tablo 1).

Tablo 1. Katılımcıların demografik özellikleri

\begin{tabular}{cccc}
\hline \multirow{3}{*}{ Cinsiyet } & & $\mathbf{f}$ & $\mathbf{\%}$ \\
\cline { 2 - 4 } & Kadın & 212 & 58.6 \\
\cline { 2 - 4 } Kıdem yılı & Erkek & 150 & 41.4 \\
& $0-5$ & 118 & 32.6 \\
\cline { 2 - 4 } & $6-10$ & 94 & 26.0 \\
\cline { 2 - 4 } & $11-15$ & 59 & 16.3 \\
\cline { 2 - 4 } & $16-20$ & 38 & 10.5 \\
\cline { 2 - 4 } Okul türü & $20+$ & 53 & 14.6 \\
& Ilkokul & 108 & 29.8 \\
\cline { 2 - 4 } & Ortaokul & 193 & 53.3 \\
\hline
\end{tabular}

Tablo 1'de görüldüğü üzere, çalışmaya 212 kadın (\%58.6) ve 150 erkek (\%41.4) öğretmen katıldı. 38 farklı öğretmenlik branşından katılımıının olduğu çalışmada, en sık karşılaşılan branşlar \%14.9 (54 kişi) ile Sınıf öğretmenliği, \%10.8 (39 kişi) ile İngilizce öğretmenliği, \%8.8 (32 kişi) ile İlköğretim matematik öğretmenliğì, \%7.7 (28 kişi) ile Türk dili ve edebiyatı öğretmenliği, \%5.8 (21'er kişi) ile Türkçe öğretmenliği ve Din kültürü ve ahlak bilgisi öğretmenliği branşlarıdır.

\section{Veri Toplama Araçları}

Bu çalışmada Hsu (2017) tarafından güncellenen öğretmen BİT entegrasyonu yeterlikleri ölçeği kullanılmıştır. Hsu tarafından ilk olarak 2010 yılında geliştirilen ölçek toplam 6 alt boyut altında 40 maddeden oluşan bir ölçekti. $\mathrm{Bu}$ çalışmada Türkçeye çevrilen ve geçerlik ve güvenirliği ölçülen ölçek ise bir önceki çalışmadaki örneklem üzerinde uygulanmak üzere geliştirilen bir devam ölçeğidir. Bu çalışmada kullanılan ölçek, 6 alt boyuttan oluşmakta ve 28 madde içermektedir. Bu 28 maddenin 23'ü bir önceki çalışmadaki 40 maddelik ölçekle ortaktır. Hsu (2017) tarafından yapılan çalışma Tayvan'da okullarda görev yapan öğretmenlerin BİT entegrasyon yeterliklerini ölçmeyi ve 3 yıllık bir sürenin sonunda BİT entegrasyon yeterliklerinde ne gibi değişiklikler olduğunu tespit etmeyi amaçlar. Bu ölçek, 6 alt boyut altında toplam 28 maddeden oluşan 4'lü (hiçbir zaman, nadiren, bazen ve çok sık) Likert tipte bir ölçektir.

Tablo 2. Hsu (2017)'nun ölçeğinde (TIPS) yer alan 6 alt boyut, madde sayıları ve güvenirlik katsayıları

\begin{tabular}{l|c|c}
\hline Alt boyut & Madde & Cronbach $\boldsymbol{\alpha}$ \\
\hline Hazırlık & 3 & 0.70 \\
\hline Üretim & 5 & 0.86 \\
\hline İletişim & 2 & 0.68 \\
\hline Öğretim & 10 & 0.94 \\
\hline Gelişim & 3 & 0.75 \\
\hline Konular/Sorunlar & 5 & 0.89 \\
\hline Toplam & 28 & 0.95 \\
\hline
\end{tabular}

Çalışmada ayrıca Hsu tarafından geliştirilen ölçeğin uyum geçerliğini ölçmek amacıyla Türel, Özdemir ve Varol (2017) tarafından geliştirilen ve öğretmenlerin bilgi ve iletişim teknolojileri becerilerine yönelik ifadeleri içeren 16 maddeden oluşan "Teachers' ICT Skills Scale” (TICTS) ölçeği kullanılmıştır. Bu ölçek kesinlikle katılmıyorum, katılmıyorum, kısmen katılmıyorum, katılıyorum ve kesinlikle katılıyorum seçeneklerinden oluşan 
beş seçenekli Likert tipte bir ölçektir. Araştırmacılar ölçeğe son halini üç aşama sonunda vermişlerdir. Birinci aşamada; 18 maddelik bir madde havuzu oluşturulmuş, ikinci aşamada; 304 öğretmenden veri toplanmış, üçüncü aşamada ise ölçeğin güvenirlik ve geçerliğini ölçmek amacıyla açımlayıcı faktör analizi yapılmıştır. Analiz sonucunda sırasıyla $.74, .85$ ve .89 Cronbach alfa değerlerine sahip üç boyutlu, 16 maddelik, geçerlik ve güvenirliği kanıtlanmış bir ölçek ortaya çıkmıştır. Ölçekte yer alan boyutlar üç maddelik 'Basit Donanım Iş̧lemleri', beş maddelik 'Bireysel BITT Kullanımı' ve sekiz maddelik 'Öğretimde BİT Kullanımı'.

\section{Çeviri Süreci}

İlk olarak, bu çalışmanın yapılabilmesi için ölçeğin geliştiricisi olan National Taiwan Üniversitesi, Öğretmen Eğitim Merkezinde profesör olarak görev yapan Shihkuan Hsu ile irtibata geçilmiş ve gerekli izinler alınmıştır. Çalışmada güvenirlik ve geçerlik analizleri yapılan ölçek ilk olarak ikisi de doktora eğitimlerini İngiltere'de tamamlamış, hem Türkçeye hem de İngilizceye akademik seviyede hakim olan araştırmacılar tarafından ayrı ayrı Türkçeye çevrilmiştir. Ölçekte yer alan tüm maddeler, büyük bir hassasiyetle maddelerin anlamı bozulmadan ama Türkçenin söyleyiş kalıplarına uydurularak Türkçeye çevrilmiştir. Sonra, birisi Türkçe dil uzmanı olan araştırmacılar tarafından ayrı ayrı yapılan çeviriler karşılaştırmalı olarak incelenmiş, gerekli değişiklikler ve düzeltmeler yapılmış ve en doğru -en uygun çeviriye beraberce karar verilmiştir. Sonraki aşamada, ölçeğin Türkçe çevirisi ölçek geliştirmede tecrübeye sahip iki uzman tarafindan incelenmiş, hem maddelerin ölçek maddesi olma yeterlikleri hem de çevirinin doğruluğu ve anlaşılırlığı değerlendirilmiştir. Uzmanlardan gelen dönütler sonucunda ölçek maddeleri tekrar gözden geçirilmiş ve gerekli değişiklikler yapılmıştır. Son aşamada ise hakkında hemfikir olunan ölçek çevirisi, başka bir İngilizce dil uzmanı tarafından tekrar İngilizceye çevrilerek ölçeğin geliştiricisine gönderilmiştir. Prof. Hsu'nun önerileri sonucunda yapılan küçük değişiklikler ile ölçeğe son hali verilmiştir.

\section{Verilerin Analizi}

Bu çalışmada Hsu (2017) tarafından geliştirilen ölçeğin Türk kültürüne çevrilmesi ve çevrilen formun psikometrik özelliklerinin ele alınması amacıyla güvenirlik ve geçerlik analizleri gerçekleştirilmiştir. Bu bağlamda güvenirliği belirleyebilmek amacıyla Cronbach alfa güvenirlik katsayısı hesaplanmıştır. Ek olarak maddeanalizleri düzeltilmiş madde-toplam korelasyonları ile incelenmiştir. TIPS geçerliğini belirleyebilmek amacıyla da yapı ve uyum geçerlikleri ele alınmıştır. Yapı geçerliği için doğrulayıcı faktör analizi kullanılmıştır. Doğrulayıcı faktör analizi, var olan bir yapıya bağlı olarak oluşturulan faktörlerin gerçek verilerle tutarlılık derecesini belirlemek amacıyla kullanılan işlevsel bir yöntemdir (Kline, 2010; Tabachnick ve Fidell, 2007).

Doğrulayıcı faktör analizinde sonuçlar yorumlanırken farklı uyum indeksleri göz önüne alınmaktadır. Bu çalışmada da Ki-kare Uyum Testinin serbestlik derecesine oranı $\left(\chi^{2} / \mathrm{df}\right)$, Comparative Fit Index (CFI), Incremental Fit Index (IFI), Standardized Root Mean Square Residual (SRMR) ve Root Mean Square Error of Approximation (RMSEA) değerleridir. Kabul edilebilir kritik noktalar olarak; $\chi^{2} / \mathrm{sd}=3$ (Briggs ve Cheek, 1986) değerleri karşımıza çıkmaktadır. CFI ve IFI için .90’ın üzerinde sonuç çıkması kabul edilebilir olduğunu ifade etmektedir (Bentler, 1990; Brown, 2006; Hooper, Coughlan ve Mullen, 2008). SRMR ve RMSEA için ise .80'den küçük olması verinin iyi uyum gösterdiğini ifade etmektedir (Hu ve Bentler, 1999; Joreskog ve Sorbom, 1993; Schreiber, vd., 2006). Doğrulayıcı faktör analizinde uyum iyiliği indekslerinin yanı sıra boyutları oluşturan maddelerin faktör yüklerinin .30’un üzerinde olması ve anlamlı olması beklenmektedir. Uyum geçerliği için de TIPS ve TICTS ölçekleri ile ilişkileri korelasyon katsayısı ile incelenmiştir.

\section{Bulgular}

\section{Güvenirlik}

TIPS'in güvenirliğini saptayabilmek amacıyla gerçekleştirilen Cronbach alfa katsayısı hem alt boyutlar hem de ölçeğin tamamı için elde edilmiştir. Cronbach alfa güvenirlik katsayısına ilişkin sonuçlar Tablo 3'de yer almaktadır.

Tablo 3. TIPS'e yönelik güvenirlik sonuçları

\begin{tabular}{lcc}
\hline Alt Boyut & Madde & Cronbach $\boldsymbol{\alpha}$ \\
\hline Hazırlik & 3 & .77 \\
Üretim & 5 & .83
\end{tabular}




\begin{tabular}{lcc} 
İletişim & 2 & .48 \\
Öğretim & 10 & .90 \\
Gelişim & 3 & .79 \\
Konular/Sorunlar & 5 & .79 \\
\hline
\end{tabular}

Tablo 3'ten görüleceği üzere, Cronbach alfa katsayısı açısından incelendiğinde ölçeğin İletişim alt boyutunun alfa değerinin .48 olduğu ve dolayısıyla .70'in üzerinde altında olduğu için güvenilir olmadığ saptanmıştır. Hazırlık $(\alpha=.77)$, Üretim $(\alpha=.83)$, Öğretim $(\alpha=.90)$, Gelişim $(\alpha=.79)$ ve Konular/Sorunlar $(\alpha=$ .79) alt boyutlarının ise yeterli güvenilirlikte oldukları belirlenmiştir.

Cronbach alfa güvenirlik katsayısı hesaplandıktan sonra TIPS’in maddelerine yönelik düzeltilmiş maddetoplam korelasyonları da incelenmiş ve Tablo 4'de sunulmuştur.

Tablo 4. TIPS'e ait düzeltilmiş madde toplam korelasyonu

\begin{tabular}{|c|c|c|c|c|}
\hline Alt Boyut & Madde & $r_{j x}$ & M & SD \\
\hline \multirow{3}{*}{ Hazırlık } & 1 & .616 & 3.64 & .65 \\
\hline & 2 & .653 & 3.57 & .62 \\
\hline & 3 & .568 & 3.19 & .74 \\
\hline \multirow{5}{*}{ Üretim } & 4 & .605 & 3.11 & .84 \\
\hline & 5 & .617 & 2.51 & .93 \\
\hline & 6 & .628 & 2.65 & .88 \\
\hline & 7 & .668 & 2.93 & .94 \\
\hline & 8 & .619 & 3.03 & .79 \\
\hline \multirow{2}{*}{ İletişim } & 9 & .319 & 2.73 & .95 \\
\hline & 10 & .319 & 1.79 & .94 \\
\hline \multirow{10}{*}{ Öğrretim } & 11 & .513 & 2.93 & .84 \\
\hline & 12 & .654 & 2.28 & .96 \\
\hline & 13 & .664 & 2.44 & .90 \\
\hline & 14 & .660 & 2.35 & .97 \\
\hline & 15 & .685 & 2.72 & .88 \\
\hline & 16 & .670 & 2.29 & 1.01 \\
\hline & 17 & .717 & 2.24 & .95 \\
\hline & 18 & .679 & 2.46 & .92 \\
\hline & 19 & .621 & 2.11 & 1.00 \\
\hline & 20 & .734 & 2.11 & .99 \\
\hline \multirow{3}{*}{ Gelişim } & 21 & .560 & 2.65 & .92 \\
\hline & 22 & .685 & 2.35 & .98 \\
\hline & 23 & .650 & 2.01 & .90 \\
\hline \multirow{2}{*}{ Konular/Sorunlar } & 24 & .613 & 3.90 & .95 \\
\hline & 25 & .643 & 3.84 & .96 \\
\hline
\end{tabular}




$\begin{array}{llll}26 & .678 & 4.12 & .89 \\ 27 & .616 & 4.07 & .79 \\ \mathbf{2 8} & .365 & 3.18 & 1.11\end{array}$

Tablo 4'de TIPS'in maddelerinin, toplam puanı yordama ve ayırt etme gücünü belirlemek amacıyla gerçekleştirilen madde analizi sonucunda ölçeğin düzeltilmiş madde-test korelasyonları görülmektedir. Madde toplam korelasyonunun incelenmesinde 0.30 ve daha yüksek olan maddelerin, bireylerin ölçülmek istenilen boyut açısından iyi derecede ayırt ettiği (Büyüköztürk, 2007) ile Cronbach alfa güvenirlik katsayısının .70'in üzerinde olması (Nunnaly, 1978) göz önüne alındığında İletişim boyutunun ölçme aracından çıkartılması gerektiğine karar verilmiş ve yapı geçerliği beş boyut ve 26 madde üzerinden gerçekleştirilmiştir.

\section{Yapı Geçerliği}

TIPS'in yapı geçerliliği için ölçeğin özgün formunda bulunan yapısının Türkçe formunun öğretmenlerde doğrulanıp doğrulanmadığını test etmek amacıyla uygulanan doğrulayıcı faktör analizine ilişkin maddelere yönelik standardize edilmiş faktör yükleri ve açıklanan varyanslar Tablo 5'de yer almaktadır.

Tablo 5. TIPS'e yönelik DFA sonuçları

\begin{tabular}{|c|c|c|c|}
\hline Madde & $\lambda$ & $\boldsymbol{\theta}$ & $R^{2}$ \\
\hline $\begin{array}{l}\text { 1. Bilgisayarı; ders notu, öğretim materyali ve sınav sorusu hazırlamak için } \\
\text { kullanırım. }\end{array}$ & .67 & 24 & .45 \\
\hline $\begin{array}{l}\text { 2. İnterneti, öğrencilere yardımcı ders materyali sağlarken bilgi aramak için } \\
\text { kullanırım. }\end{array}$ & .76 & .17 & .57 \\
\hline $\begin{array}{l}\text { 3. Öğretim programı ve dersin kazanımlarına uygun BİT temelli materyalleri seçmek } \\
\text { için zaman harcarım. }\end{array}$ & .76 & .23 & .58 \\
\hline 4. Derste sunum yazılımları (Powerpoint vb.) kullanırım. & .71 & .35 & .50 \\
\hline $\begin{array}{l}\text { 5. Ders esnasında donanım sorunlarını çözerim. (Örneğin, sunum cihazına sinyal } \\
\text { gelmeme veya bilgisayarın arızalanması). }\end{array}$ & .69 & .45 & .48 \\
\hline $\begin{array}{l}\text { 6. Teknoloji tabanlı ders tasarlamak için öğretim programlarında yer alan yeterlik } \\
\text { göstergelerini dikkate alırım. }\end{array}$ & .70 & .40 & .49 \\
\hline $\begin{array}{l}\text { 7. Bilgisayarı, ders materyallerine ses ve müzik kaydetme ya da onları düzenleme } \\
\text { amaçlı kullanırım. }\end{array}$ & .71 & .44 & .50 \\
\hline 8. Teknolojiyi, öğretimde yeni yöntemleri deneme amaçlı kullanırım. & .71 & .30 & .51 \\
\hline $\begin{array}{l}\text { 11. Öğrencilere, dersleri için faydalı kaynakları İnternette nasıl araştıracaklarını } \\
\text { ögretirim. }\end{array}$ & .58 & .47 & .34 \\
\hline 12. Bilgi teknolojileri destekli derslerde grup çalışmaları yaptırırım. & .70 & .46 & .50 \\
\hline $\begin{array}{l}\text { 13. Tüm öğrencilerin ödevlerini tamamlamaları için yeterli BİT kaynağına ve gerekli } \\
\text { becerilere sahip olduğundan emin olurum. }\end{array}$ & .71 & 40 & .51 \\
\hline $\begin{array}{l}\text { 14. Ödevlerini hazırlarken İnternet araçlarından faydalanmaları gerektiğinde, } \\
\text { ögrencilere yönergeli çalışma kâğıtları hazırlarım. }\end{array}$ & .70 & .48 & .49 \\
\hline $\begin{array}{l}\text { 15. Öğrencilerin yaratıcılık, çözümleme ve bir yargıya varma gibi üst düzey düşünme } \\
\text { becerileri geliştirmeleri için BİT'den faydalanırım. }\end{array}$ & .75 & .34 & .56 \\
\hline $\begin{array}{l}\text { 16. Geleneksel değerlendirme yöntemlerine alternatif olarak öğrencilere not verirken } \\
\text { onların bilgi teknolojilerine ilişkin performanslarını göz önünde bulundururum. }\end{array}$ & .66 & .58 & .43 \\
\hline $\begin{array}{l}\text { 17. Öğrencilerin BİT destekli derslerde yapılan grup çalışmalarındaki öğrenme } \\
\text { gelişimlerini analiz eder ve bunları değerlendirmeye dahil ederim. }\end{array}$ & .70 & .45 & .49 \\
\hline $\begin{array}{l}\text { 18. Dersin niteliğini iyileştirme yollarını bulmak için kendi BİT tabanlı stratejimi } \\
\text { gözden geçiririm. }\end{array}$ & .73 & .40 & .53 \\
\hline $\begin{array}{l}\text { 19. Evde bilgisayarı bulunmayan öğrencilerin de yapabileceği BİT destekli ev } \\
\text { ödevleri tasarlarım. }\end{array}$ & .61 & .62 & .37 \\
\hline $\begin{array}{l}\text { 20. Farklı başarı düzeyine sahip öğrenciler için farklı BİT öğrenme etkinlikleri } \\
\text { tasarlarım. }\end{array}$ & .75 & .43 & .56 \\
\hline 21. BİT becerilerini öğrenmek ve uygulamak için zaman harcarım. & .73 & .39 & \\
\hline
\end{tabular}


22. Mesleki gelişimim için çevrimiçi kurslara katılır ya da çevrimiçi veri tabanlarını kullanırım.

23. Derslerde BİT 'den yararlanmak için akademik dergileri okur veya konferanslara katılırım.

24. İnterneti kullanmadan önce öğrencilere, internet etiği ve kurallara ilişkin konuları öğretirim.

25. Öğrencilerden fikri mülkiyet haklarına uymalarını isterim.

26. Gençlerin internet ve yetişkin web sitelerine bağımlılığına ilişkin problemlerin farkındayım.

27. Öğrencileri, Bilgi Teknolojileri araçlarını kullanmanın insan sağlığına verebileceği zararlar hakkında bilgilendiririm.

28. İnternet bağımlılığından dolayı keyifsiz/neşesiz olan ve değişken notlara sahip öğrencileri takip ve kontrol ederim.

$.68 \quad .48 \quad .46$

$.80 \quad .33 \quad .64$

$.80 \quad .28 \quad .64$

$\begin{array}{lll}.68 & .33 \quad .47\end{array}$

Not. $\lambda=$ standartlaştırılmış faktör yükleri factor loadings; $\theta=$ hata varyansı

TIPS'in maddelerinin faktör yükleri .42 ile .80 arasında değişmekte olup faktör yüklerinin .30'un üzerinde ve anlamlı olduğu anlaşılmaktadır. Ölçeğin uyum indekslerinin $\left[\chi^{2}(287, \mathrm{~N}=362)=749.07, \chi^{2} / \mathrm{sd}=2.61 ; \mathrm{CFI}=.90 ; \mathrm{IFI}=\right.$ $.90 ;$ SRMR = .077; RMSEA = $.067 \% 90$ G.A. $(.061-.073)]$ şeklinde olduğu görülmektedir. Dolayısıyla TIPS'in yapı geçerliğini sağladığı ifade edilebilir. Doğrulayıcı faktör analizi sonuçlarının kriterleri karşılama durumlarına yönelik bulgular Tablo 6'da sunulmuştur.

Tablo 6. TIPS'e İlişkin Doğrulayıcı Faktör Analizi Sonuçları

\begin{tabular}{lccc}
\hline Uyum indeksi & Hesaplanan Değer & Kabul Edilebilir Değerler & Sonuç \\
\hline$\chi^{2} /$ sd & 2.61 & $\chi^{2} / \mathrm{sd} \leq 5.00$ & Kabul \\
CFI & .90 & $\mathrm{CFI} \geq .90$ & Kabul \\
IFI & .90 & TLI $\geq .90$ & Kabul \\
SRMR & .077 & SRMR $\leq .08$ & Kabul \\
RMSEA & .067 & RMSEA $\leq .08$ & Kabul \\
\hline
\end{tabular}

Not: Kabul edilebilir değerler için Bollen, 1990, Hooper, Coughlan ve Mullen, 2008, Hu ve Bentler, 1999 ile Joreskog ve Sorbom 1993 'ün önerileri dikkate alınmıştır.

\section{Uyum Geçerliği}

TIPS'in uyum geçerliği kapsamında Türel, Özdemir ve Varol (2017) tarafından Türkçeye uyarlanan TICTS ölçeği ile ilişkileri ele alınmıştır. TIPS ile TICTS arasındaki ilişsilere ait bulgular Tablo 7'de yer almaktadır.

Tablo 7. TIPS'in uyum geçerliğine yönelik bulgular

\begin{tabular}{lccc}
\hline Alt Boyut & Basit donanım işlemleri & Bireysel BİT kullanımı & Öğretimde BİT kullanımı \\
\hline Hazırlık & $.31^{* *}$ & $.43^{* *}$ & $.58^{* *}$ \\
Üretim & $.50^{* *}$ & $.61^{* *}$ & $.63^{* *}$ \\
Öğretim & $.37^{* *}$ & $.55^{* *}$ & $.48^{* *}$ \\
Gelişim & $.43^{* *}$ & $.59^{* *}$ & $.50^{* *}$ \\
Konular/Sorunlar & $.47^{* *}$ & $.63^{* *}$ & $.62^{* *}$ \\
\hline
\end{tabular}

Not: ${ }^{* *} p<.001$

Uyum geçerliği kapsamında ele alınan TIPS ile TICTS arasındaki ilișkilerde pozitif yönde anlamlı ilișkiler görülmüştür. Boyutlar tek tek incelendiğinde; hazırlık; basit donanım işlemleri $(r=.31, p<.01)$, bireysel BİT kullanımı $(r=.43, p<.01)$ ve öğretimde BİT kullanımı $(r=.58, p<.01)$ ile ilişkileri görülmüştür. Üretim boyutu; basit donanım işlemleri $(r=.50, p<.01)$, bireysel BİT kullanımı $(r=.61, p<.01)$ ve öğretimde BİT kullanımı $(r$ $=.63, p<.01)$ ile ilişkilere sahiptir.

Ek olarak, ögretim ile basit donanım işlemleri $(r=.37, p<.01)$, bireysel BíT kullanımı $(r=.55, p<.01)$ ve öğretimde BİT kullanımı $(r=.48, p<.01)$ ile ilişkiler saptanmıştır. Benzer şekilde, gelişim boyutu ile basit donanım işlemleri $(r=.43, p<.01)$, bireysel BİT kullanımı $(r=.59, p<.01)$ ve öğretimde BİT kullanımı $(r=.50$, 
$p<.01)$ arasında pozitif yönde anlamlı ilişkiler bulunmuştur. Son olarak, konular/sorunlar boyutu ile basit donanım işlemleri $(r=.47, p<.01)$, bireysel BİT kullanımı $(r=.63, p<.01)$ ve öğretimde BİT kullanımı $(r=.62, p<.01)$ arasında da pozitif yönde anlamlı ilişkiler elde edilmiştir. Tüm bu sonuçlar 1şı̆̆ında TIPS'in uyum geçerliğine sahip olduğu ifade edilebilir.

\section{Sonuç ve Öneriler}

$\mathrm{Bu}$ araştırmanın amacı öğretmenler için bilgi ve iletişim teknolojileri entegrasyonu yeterlikleri (TIPS) ölçeğini Türkçeye çevirmek ve ölçeğin geçerlilik ve güvenilirlik analizlerini yapmaktır. Ölçeğin geçerliğini belirleyebilmek için yapı ve uyum geçerliğini kullanılmıştır. Yapı geçerliği için gerçekleştirilen doğrulayıcı faktör analizinde ölçeğin Türkçe formunun beş boyutlu olduğu ve bu modelin iyi uyum sağladığ görülmüştür $\left(\chi^{2}=151.58, \mathrm{SD}=53\right.$, RMSEA $=0.08, \mathrm{GFI}=0.93, \mathrm{AGFI}=0.88, \mathrm{CFI}=0.95, \mathrm{NFI}=0.91, \mathrm{NNFI}=0.96$ ). Uyum geçerliğinde TIPS ile TICTS arasında anlamlı ilişkiler olduğu görülmüştür. Ölçeğin güvenirliğini belirlemek için ise Cronbach alfa katsayısı ve madde-toplam korelasyonlarına bakılmıştır. Ölçeğin Cronbach alfa iç tutarlılık güvenirlik katsayıları hazırlık $(\alpha=$ .77), üretim ( $\alpha=.83)$, öğretim $(\alpha=.90)$, gelişim $(\alpha=.79)$ ve konular/sorunlar $(\alpha=.79)$ boyutlarında yeterli güvenilirlikte oldukları belirlenmiştir. Madde toplam korelasyonunun incelenmesinde 0.30 ve daha yüksek olan maddelerin, bireylerin ölçülmek istenilen boyut açısından iyi derecede ayırt ettiği ile Cronbach alfa güvenirlik katsayısının .70'in üzerinde olması göz önüne alındığında İletişim boyutunun ölçme aracından çıkartılması gerektiğine karar verilmiş beş boyut ve 26 madde üzerinden gerçekleştirilmiştir. Ulaşılan bu sonuçlar ölçeğin Türkçe formunun geçerli ve güvenilir bir ölçme aracı olduğunu göstermektedir.

Sonuç olarak Türkçeye uyarlanan öğretmenler için bilgi ve iletişim teknolojileri entegrasyonu yeterlikleri ölçeğinin beş boyuttan oluştuğu, bu modelin araştırmaya katılan öğretmenlerden elde edilen verilerle uyumlu olduğu, ölçeğin boyutlarının iç tutarlık katsayılarının yeterli düzeyde olduğu ve ölçeğin amacına hizmet ettiği anlaşılmıştır. Bu sonuçlar dikkate alındığında, farklı branşlarda ve farklı okul türlerinde (ilkokul, ortaokul ve lise) görev alan tüm öğretmenlerin bilgi ve iletişim teknolojileri entegrasyonu yeterliklerinin zaman içindeki değişimlerini ölçülmesinde Türkçeye uyarlanan TIPS'in kullanılabileceği anlaşılmaktadır. Uyarlanan ölçeğin kullanıldığı araştırmalardan elde edilecek sonuçların geçerlilik ve güvenilirliğe ait kanıtların desteklenmesine katkı sağlayacağı düşünülmektedir. Bu ölçeğin Türkçe formunu kullanarak elde edilen veriler ile diğer ülkelerdeki öğretmenlerin BİT entegrasyonu yeterlikleriyle ilgili bilimsel verilerle karşılaştırmak mümkün olacaktır. Ayrıca, TIPS’ in farklı örneklemler ile yeniden geçerlilik ve güvenilirlik çalışmaları yapılabilir. 


\section{References}

Artun, H., \& Günüç, S. (2016). Student's perception scale about instructors' technology integration competence: validity And reliability study. YYU Journal of Education Faculty, 13(1), 544-566.

Bentler, P. M. (1990). Comparative fit indexes in structural models. Psychological Bulletin, 107(2), 238.

Bollen, K.A. (1990). Overall Fit in covariance structure models: Two types of sample size effects. Psychological Bulletin, 107(2), 256-59.

Briggs, S. R., \& Cheek, J. M. (1986). The role of factor analysis in the development and evaluation of personality scales. Journal of Personality, 54, 106-148

Brown, T. A. (2006). Confirmatory Factor Analysis for Applied Research. New York: Guilford Press.

Büyüköztürk, Ş. (2007). Sosyal bilimler için veri analizi el kitabı. Ankara: Pegem Yayınevi.

Cenker, B., \& Akgül, E. M. (2011). Investigation of elementary school teachers' understandings on change management in schools. Sakarya University Journal of Education, 1(1), 6-14.

Christensen, R. (2002). Effects of technology integration education on the attitudes of teachers and students. Journal of Research on Technology in Education, 34(4), 411-433.

Çağıltay, K., Çakıroğlu, J., Çağıltay, N., \& Çakıroğlu, E. (2001). Teachers’ perspectives about the use of computers in education. Hacettepe Journal of Education, 21(1), 19-28.

Çakıroğlu, Ü., Gökoğlu, S., \& Çebi, A. (2015). Basic indicators for teachers' technology integration: a scale development study. Gazi University Gazi Journal of Faculty of Education, 35(3), 507-522.

Çırak, S., \& Demir, S. (2014). Examining classroom teachers' views about their competencies concerning the integration of technology. Gaziantep University Journal of Social Sciences, 13(1), 99-113.

Çoklar, A. N., \& Yurdakul, I.K. (2017). Technology integration experiences of teachers. Discourse and Communication for Sustainable Education, 8(1), 19-31.

Davies, R. (2011). Understanding technology literacy: A framework for evaluating educational technology integration. Techtrends. Linking Research \& Practice to Improve Learning, 55(5), 45-52. doi:10.1007/s11528-011-0527-3.

Erişti, S. D., Kurt, A. A., \& Dindar, M. (2012). Teachers' views about effective use of technology in classrooms. Turkish Online Journal of Qualitative Inquiry, 3(2), 30-41.

Ertmer, P. A. (2005). Teacher pedagogical beliefs: The final frontier in our quest for technology integration. Educational Technology Research and Development, 53(4), 25-39.

Ertmer, P. A., \& Ottenbreit-Leftwich, A. T. (2010). Teacher technology change: How knowledge, confidence, beliefs, and culture intersect. Journal of Research on Technology in Education, 42(3), 255-284.

Haşlaman, T., Kuşkaya-Mumcu, F., \& Usluel, Y. K. (2007). The integration of information and communication technologies in learning and teaching process: A lesson plan example. Eğitim ve Bilim Dergisi, 32(146), 54-63.

Hew, K. F., \& Brush, T. (2007). Integrating technology into K-12 teaching and learning: Current knowledge gaps and recommendations for future research. Educational Technology Research and Development, 55(3), 223252.

Hooper, D., Coughlan, J., \& Mullen, M. (2008). Structural equation modelling: Guidelines for determining model fit. Electronic Journal of Business Research Methods, 6, 53-60.

Howard, R.M., \& Davies, L.J. (2009). Plagiarism in the Internet Age. Educational Leadership, 66(6), 64-67.

Hsu, S. (2010a). The relationship between teacher's technology integration ability and usage. Journal of Educational Computing Research, 43(3), 309-325. 
Hsu, S. (2010b). Developing a scale for teacher integration of information and communication technology ingrades 1-9. Journal of Computer Assisted Learning, 26, 175-189. doi: 10.1111/j.1365-2729.2010.00348.x.

Hsu, S. (2017). Developing and validating a scale for measuring changes in teachers' ICT integration proficiency over time. Computers \& Education, 111, 18-30.

Hu, L. T., \& Bentler, P. M. (1999). Cut off criteria for fit indexes in covariance structure analysis: Conventional criteria versus new alternatives. Structural Equation Modeling: A Multidisciplinary Journal, 6(1), 1-55.

Ilgaz, H., \& Usluel, Y. (2011). Teacher competencies according to ICT integration into the teaching processes and professional development. Ĕgitim Bilimleri ve Uygulama, 10(19), 87-106.

International Society for Technology in Education [ISTE](2014). ISTE Standards Teachers. http://www.iste.org/docs/pdfs/20-14_ISTE_Standards-T_PDF.pdf.

Jacobs, H. H. (2010). Curriculum 21: Essential education for a changing world. Alexandria, Virginia.

Jöreskog, K., \& Sörbom, D. (1993). LISREL 8: Structural Equation Modeling with the SIMPLIS Command Language. Chicago, IL: Scientific Software International Inc.

Kafyulilo, A., Fisser, P., \& Voogt, J. (2016). Teacher design in teams as a professional development arrangement for developing technology integration knowledge and skills of science teachers in Tanzania. Education and Information Technologies, 21(2), 301-318. doi:10.1007/s10639-014-9321-0.

Kline, R. B. (2010). Principles and practice of structural equation modeling (3rd ed.). New York: The Guildford Press.

Lawrence, J. E. \& Tar, U. A. (2018). Factors that influence teachers' adoption and integration of ICT in teaching/learning process. Educational Media International, 55(1), 79-105, DOI: 10.1080/09523987.2018.1439712.

Lim, C. P. (2007). Effective integration of ICT in Singapore schools: Pedagogical and policy implications, Education Technology Research Development, 55, 83-116.

Mazman, S. G., \& Usluel, Y. K. (2011). ICT integration into learning-teaching process: models and indicators. Educational Technology theory and practice, 1(1), 62-79.

Misırlı, Z. A. (2016). Integrating technology into teaching and learning using variety of models. Ihlara Ĕ̈itim Araştırmaları Dergisi, 1(2), 37-48.

Milli Eğitim Bakanlığı [MEB] (2017). Öğretmenlik mesleği genel yeterlilikleri. Öğretmen Yetiştirme ve Eğitimi Genel Müdürlüğü, Ankara.

Mumcu, F. K., Haşlaman, T., \& Usluel, Y. K. (2008). Teknolojik pedagojik içerik bilgisi modeli çerçevesinde etkili teknoloji entegrasyonunun göstergeleri. 8th International Educational Technology Conference, Anadolu University, Eskişehir, 296-299.

Niederhauser, D. S., \& Perkmen, S. (2008) Validation of the intrapersonal technology integration scale: assessing the influence of intrapersonal factors that influence technology integration. Computers in the Schools, 25(12), 98-111, DOI:10.1080/07380560802157956.

Nunnally, J.C (1978). Psychometric Theory. Newyork: Mcgraw Hill.

Öçal, M., \& Şimşek, M. (2017). Pre-service mathematics teachers' opinions about FATİH project and technology use in mathematics education. Turkish Online Journal of Qualitative Inquiry, 8(1), 91-121. DOI: 10.17569/tojqi.288857

Özerbaş, M. F. (2010). The evaluation on technological problems faced within the application of new program from the teachers' perspective. Ahi Evran University Journal of Faculty of Education, 11(2), 267-283.

Pittman, T. \& Gaines, T. (2015). Technology integration in third, fourth and fifth grade classrooms in a Florida school district. Educational Technology Research and Development, 63(4), 539-554. DOI 10.1007/s11423015-9391-8.

Schreiber, J. B., Nora, A., Stage, F. K., Barlow, E. A., \& King, J. (2006). Reporting structural equation modeling and confirmatory factor analysis results: A review. The Journal of Educational Research, 99(6), 323-338

So, H.J, \& Kim, B. (2009). Learning about problem based learning: Student teachers integrating technology, pedagogy and content knowledge. Australasian Journal of Educational Technology, 25(1), 101-116.

Tabachnick, B. G., \& Fidell, L. S. (2007). Using multivariate statistics (5th ed.). Boston, Allyn and Bacon. 
Tezci, E. (2011). Turkish primary school teachers' perceptions of school culture regarding ICT integration. Educational Technology Research and Development, 59, 429-443.

Tezci, E. (2016). Developing a scale for measuring ICT integration approaches for teachers. Kastamonu Education Journal, 24(2), 975-992.

Tondeur, J., van Braak, J., \& Valcke, M. (2007). Curricula and the use of ICT in education: Two worlds apart?. British Journal of Educational Technology, 38, 962-976.

Tsai, H. C. (2015). A senior teacher's implementation of technology integration. International Education Studies, $8(6), 151-161$.

Türel, Y.K., Özdemir, T.Y., \& Varol, F. (2017). Teachers' ICT skills scale: Reliability and Validity. Cukurova University Faculty of Education Journal 46(2), 503-516.

Yalın, H. İ., Karadeniz, S., \& Şahin, S. (2007). Barriers to information and communication technologies integration into elementary schools in Turkey. Journal of Applied Sciences, 7(24), 4036-4039.

Yu-Liang, T. (2011). Introducing new technology to teachers: A pilot evaluation. International Journal of Technology in Teaching \& Learning, 7(2), 136-151. 